\title{
The Procedure for Enforcement of Article 101 and
}

\section{TFEU}

\begin{abstract}
Administration is ordinarily discussed as the art of getting things done. Emphasis is placed upon processes and methods for ensuring incisive action.
\end{abstract}

HERBERT A. SIMON

In this part chapter, I set out to test whether the European Commission is an independent and impartial tribunal when it enforces European competition law. This question has been prompted by the fact that the European Commission appears to cumulate investigative, prosecutorial and adjudicative functions, and by the growing case-law of the ECtHR that suggests such institutional set-ups pose a threat to the independent delivery of administrative justice. Chapter 9 above was dedicated to understanding the political-bureaucratic interface that defines the Commission's work and the elements that seek to guarantee the Commission's independence at the macro level. The current chapter is dedicated to analysing the procedure for the enforcement of Articles 101 and 102 TFEU and the existing fair trial guarantees.

European competition law has known for a very long time only one enforcement procedure. Under this procedure, the European Commission collected evidence concerning an alleged breach of Articles 101 or 102 TFEU and adopted a prohibition decision against one or more undertakings, imposing fines or remedies.

The development of competition law and policy in Europe has led to the adoption of new enforcement procedures that, despite being intended for exceptional cases, are widely used by the Commission. These procedures include the commitment procedure, under which the Commission will reach an agreement with the undertakings involved and will adopt that agreement as binding, and the settlement procedure, which can take two forms, informal and formal. It is thought that the settlement procedure has eased the burden placed on the undertakings. As one author noted 
cartel investigations are comparatively frequent and procedural costs may be high because of the multiplicity of parties and languages involved and the fact that the average cartel file numbers tens of thousands of pages, all of which have to be screened for confidentiality issues, while only a few hundred of those pages, on average, are actually used in evidence. ${ }^{1}$

In the following section I describe the procedure used for the enforcement of Articles 101 and 102 TFEU and the Commission's powers of investigation. I conclude with the mapping of the due process guarantees accompanying the procedure. The purpose of this mapping exercise is to grasp whether the guarantees offered during this procedure are sufficient to conclude that, when enforcing EU competition law, the European Commission acts as an independent and impartial tribunal.

\subsection{The Investigation Phase}

\subsubsection{Complaints}

When the Commission believes that a breach of Articles 101 or 102 TFEU has taken place, it may decide to open an investigation. The case may originate from a formal complaint, from the Commission's own initiative (ex officio), or from leniency applications submitted by one or more participants in the cartel. In addition to this, the Notice on Best Practices points that information from citizens and undertakings is important in triggering investigations by the Commission and the Commission, therefore, encourages "citizens and undertakings to inform it about suspected infringements of the competition rules". ${ }^{2}$ Recently, the Commission has created whistleblowing tools that allow individuals to share market information anonymously with the Commission.

Informal complaints - that is information voluntarily offered to the Commission outside the framework of a formal investigation - may reach the Commission from various sources and in various forms, without creating any rights for the person offering the information or duties for the Commission. The regulations contain very little guidance as to the legal status of informal complaints and the case-law has rarely considered this matter.

1 Tierno Centella, Maria Luisa. "The New Settlement Procedure in Selected Cartel Cases." Competition Policy Newsletter 3 (2008), p. 31.

2 Commission notice on best practices for the conduct of proceedings concerning Articles 101 and 102 TFEU, oJ C 308, 20.10.2011, pp. 6-32, p.10. 
Very little is known about the number of informal complaints received by the Commission, about how this information is stored, accessed and used. The same is true about the information received via the whistleblowing tools, which are in fact simply an e-mail address and a telephone number.

Formal complaints are complaints that fulfil the formal and substantive conditions required by EU legislation. First, the complaint must be formulated by a legal or natural person who has a "legitimate interest" in the case, meaning "any person who could plausibly claim to have suffered as the result of an infringement". ${ }^{3}$ The following categories of applicants are considered to have legitimate interest to lodge a complaint with the Commission: competitors, trade unions, trade associations, associations of undertakings, consumer associations and even individual consumers. Member states are privileged complainants; they are presumed to have legitimate interest in all cases for which they choose to lodge a complaint.

The rules concerning the content of a complaint are enumerated in Article 7(2) of Regulation 1/2003, Article 5(1) of the Implementing Regulation and Form $\mathrm{C}$ annexed to the latter. The complainant should provide copies of the documents that prove the allegations or otherwise indicate where the Commission can obtain them. The Commission can also dispense the complainant from the duty to provide information when it considers that such information does not serve the purpose of the case and is therefore irrelevant.

The complainant can request anonymity and provide explanations as to why the Commission has to protect its identity. In cases when the Commission considers the complainant's request for anonymity justified, it will not disclose the complainant's identity to the companies concerned. The complainant also bears the initial responsibility for identifying the confidential information in its complaint or any business secrets.

Complaints do not give rise to an automatic right to obtain a decision. The Commission alone has the discretion to decide when to initiate an investigation.

In Automec, the applicant argued that the Commission has the duty to investigate all complains. The Court of Justice disagreed with the applicant arguing first of all that European Community legislation indeed required the Commission to respect some procedural rights of applicants during its investigations. However, the Commission could not be compelled to carry out an investigation. The Court concluded that

3 European Commission. Dealing with the Commission Notifications: complaints, inspections and fact-finding powers under Articles 85 and 86 of the EEC Treaty. Luxembourg: Office for Official Publications of the European Communities, 1997, p. 18. 
in the case of an authority entrusted with a public service task, the power to take all the organizational measures necessary for the performance of that task, including setting priorities within the limits prescribed by the law - where those priorities have not been determined by the legislature - is an inherent feature of administrative activity. This must be the case in particular where an authority has been entrusted with a supervisory and regulatory task as extensive and general as that which has been assigned to the Commission in the field of competition. Consequently, the fact that the Commission applies different degrees of priority to the cases submitted to it in the field of competition is compatible with the obligations imposed on it by Community law. ${ }^{4}$

The Commission refers to the community interest in order to determine the degree of priority to be applied to the complaints it receives. In Automec, the Court of Justice made the distinction

that, unlike the civil courts, whose task is to safeguard the individual rights of private persons in their relations inter se, an administrative authority must act in the public interest. Consequently, the Commission is entitled to refer to the Community interest in order to determine the degree of priority to be applied to the various cases brought to its notice. This does not amount to removing action by the Commission from the scope of judicial review, since, in view of the requirement to provide a statement of reasons laid down by Article 19o of the Treaty, the Commission cannot merely refer to the Community interest in the abstract. It must set out the legal and factual considerations which led it to conclude that there was insufficient Community interest to justify investigation of the case. It is therefore by reviewing the legality of those reasons that the Court can review the Commission's action. ${ }^{5}$

Community interest thus cannot be defined in abstracto; the Commission performs a factual and legal analysis of the particulars of each case. The Court indicated that the Commission should, in particular, balance the significance of the alleged infringement as regards the functioning of the common market, the probability of establishing the existence of the infringement and the scope

4 T-24/9o, Automec v Commission, ECLI:Eu:T:1992:97, paragraph 77.

5 T-24/9o, Automec $v$ Commission, quoted above, paragraph 85 . 
of the investigation required in order to fulfil, under the best possible conditions, its task of ensuring respect for competition law. ${ }^{6}$

In practice, the Commission has discretion to grant priority to cases which present a community interest and reject complaints that do not justify further investigation. This initial assessment is not public and very little is known about who handles these cases within DG COMP and who participates in the decision not to investigate.

The Notice on the Handling of Complaints indicates that the number of criteria for the assessment of the community interest to which the Commission may refer is not limited, nor is the Commission required to have recourse exclusively to certain criteria. As the factual and legal circumstances may differ considerably from case to case, it is permissible to apply new criteria which had not been considered before. ${ }^{7}$

\subsubsection{Allocation of Cases}

An important part of the initial assessment performed by the Commission is the allocation of cases within the ECN. Regulation 1/2003 introduced the general principle of parallel competences according to which all competition authorities have the power to apply Articles 101 and 102 TFEU. A corollary of this principle is the rule that a case could be re-allocated to another network member if the latter is better placed to deal with it.

Competence to deal with Article 101 and 102 TFEU complaints may belong to one NCA, a few NCA s in parallel or to the Commission. The Commission may not exercise enforcement activities in parallel with other NCAs. The Network Notice indicates that in most instances, the authority that receives a complaint will remain in charge of the case. Re-allocation of cases within the network should thus be exceptions and should be performed at the outset of the procedure. ${ }^{8}$ The re-allocation procedure should be a quick and effective process and not hold up on-going investigations. ${ }^{9}$ Case re-allocation issues should be resolved swiftly, within a maximum of two months from the date when the first information about the case is circulated. ${ }^{10}$

6 T-24/9o, Automec v Commission, quoted above, paragraph 86.

7 Commission Notice on the handling of complaints by the Commission under Articles 81 and 82 of the EC Treaty, OJ C 101, 27.4.2004, pp. 65-77, p. 70 .

8 Commission Notice on the handling of complaints by the Commission under Articles 81 and 82 of the EC Treaty, quoted above, p. 65 .

9 Commission Notice on the handling of complaints by the Commission under Articles 81 and 82 of the EC Treaty, quoted above, p. 65 .

10 Commission Notice on the handling of complaints by the Commission under Articles 81 and 82 of the EC Treaty, quoted above, p. 67 . 
The rule on the basis of which the competent authority is chosen is the well placed authority to deal with the case. The Network Notice explains that a wellplaced authority should fulfil the following three cumulative conditions:

- The agreement of practice has substantial direct actual or foreseeable effects on competition within its territory, is implemented within or originates from its territory;

- The authority is able to effectively bring to an end the entire infringement, i.e., it can adopt cease-and-desist order the effect of which will be sufficient to bring an end to the infringement and it can where appropriate, sanction the infringement adequately;

- The authority can gather, possibly with the help of other such authorities, the evidence required to prove such infringement. ${ }^{11}$

The notice indicates that the Commission is particularly well-placed if one or several agreements or practices have effects on competition in more than three member states (cross-border markets covering more than three member states or several national markets). ${ }^{12}$

The question of forum shopping was raised in France Télécom where the undertaking had been fined earlier by the Commission, but complaints against it kept being lodged at the Commission. ${ }^{13}$ The case was investigated by the French NCA when the Commission requested to investigate its premises.

The Court noted that with regard, first of all, to the division of powers between the Commission and the NCAs, Regulation No 1/2003 put an end to the previous centralised regime and, in accordance with the principle of subsidiarity, established a wider association of NCAs, authorising them to implement European Community competition law for this purpose. However, the scheme of the regulation relies on the building-up of close cooperation between the Commission and the competition authorities of the member states organised as a network, the Commission being given responsibility for determining the detailed rules for such cooperation. Furthermore, the regulation does not call into question the general power that the Commission is acknowledged to enjoy by the case-law. The Court concluded that "the Commission in effect has very wide powers of investigation under Regulation No $1 / 2003$ and is in any event entitled to decide to initiate proceedings relating to an infringement, which entails removing the case from the Member State's

11 Commission Notice on the handling of complaints by the Commission under Articles 81 and 82 of the EC Treaty, quoted above, p. 66.

12 Commission Notice on the handling of complaints by the Commission under Articles 81 and 82 of the EC Treaty, quoted above, p. 66.

13 T-339/04, France Télécom v Commission, ECLI:EU:T:2007:80. 
competition authorities. The Commission thus retains a leading role in the investigation of infringements". ${ }^{14}$ In fact, it may take over a case even when a national authority is investigating it, provided that the Commission explains to the national authority and to the other members of the network the reasons for the takeover. ${ }^{15}$

The Court has also considered the content of the obligation to cooperate in good faith within the ECN. The Court found that "the principle of cooperation means that the Commission and the national competition authorities may, at least in the preliminary stages of the cases with which they deal, work in parallel". 16

Commenting on the France Télécom case, Monti argued that the ECJ had yet to pronounce itself about the operation of the re-allocation of cases system, but in its judgments, it has given strong indications that the Commission enjoys extensive powers over NCA s. He concluded that the competence to apply competition law in the EU is not parallel, but concurrent: "the NCA has the power to apply EU competition law only up to the point when the Commission decides to exercise its powers. At that moment the Member States' executive competence is suspended". ${ }^{17}$

\subsubsection{Initial Assessment and Duty of Vigilance}

Lodging a complaint with the European Commission alleging an infringement of EU competition law triggers what is called the duty of vigilance. Van Bael has written that the duty of vigilance means that the Commission "should examine the facts and legal arguments put forward carefully and impartially in order to decide whether the competition rules of the Treaty were infringed in a given case". 18

The European Courts themselves do not use the term "duty of vigilance", but note that the Commission is obliged "to examine carefully the factual and legal particulars brought to its notice by the complainant in order to decide whether they disclose conduct of such a kind as to distort competition in the common market and affect trade between Member States".19

$14 \mathrm{~T}-339 / 04$, France Télécom v Commission, quoted above, paragraph 79.

$15 \mathrm{~T}-339 / 04$, France Télécom $v$ Commission, quoted above, paragraph 85.

16 T-339/o4, France Télécom v Commission, quoted above, paragraph 86.

17 Monti, Giorgio. "Legislative and Executive Competences in Competition Law." The Question of Competence in the European Union. Ed. Loic Azoulai. Oxford: Oxford University Press, 2014, p. 116.

18 Van Bael, op. cit., p. 122.

19 T-24/9o, Automec v Commission, quoted above, paragraph 79. 
Turning now to the assessment itself of complaints that the Commission has to perform, the GC identified three stages in Automec I. This practice was gradually consolidated into the legislation.

First, following the submission of a complaint, the Commission has to collect the information that will serve as the basis for the decision that it will later adopt. The Court explained that this "stage may include inter alia an informal exchange of views and information between the Commission and the complainant with a view to clarifying the factual and legal issues with which the complaint is concerned and to allowing the complainant an opportunity to expand on his allegations in the light of any initial reaction from the Commission". ${ }^{20}$ At this stage, the Commission may give an initial reaction to the complainant allowing the latter an opportunity to understand the Commission's point of view and to expand on the allegations in light of that initial reaction. $^{21}$

The Court notes that the preliminary observations made by Commission officials in the context of informal contacts cannot be regarded as measures open to challenge. ${ }^{22}$

During the second stage, the Commission may investigate the case further with a view to initiating proceedings. Where the Commission considers that there are insufficient grounds for acting on the complaint, it will inform the complainant of its reasons and offer the complainant the opportunity to submit any further comments within a time limit which it fixes. ${ }^{23}$

The Court of Justice ruled that this notification is similar to a statement of objections. However, whereas the statement of objections must guarantee the observance of the right to a fair hearing, the notification under discussion "is intended to defend the procedural rights of the complainants, which are, however, not as far-reaching as the right to a fair hearing of the companies which are the object of the Commission's investigation". ${ }^{24}$ The Court added that it was clear from the judgment in $I B M$ that the statement of objections was not a decision, but merely a procedural measure preparatory to the final decision. Thus, "if that is true of the statement of objections, the legal importance of

20 T-64/89, Automec v Commission, ECLI:EU:T:199o:42, paragraph 45.

21 Commission Notice on the handling of complaints by the Commission under Articles 81 and 82 of the Ec Treaty, quoted above, p. 71 .

$22 \mathrm{~T}-64 / 89$, Automec $v$ Commission, quoted above, paragraph 45.

23 Commission Notice on the handling of complaints by the Commission under Articles 81 and 82 of the EC Treaty, quoted above, p. 71 .

24 T-64/89, Automec v Commission, quoted above, paragraph 46. 
which is greater than that of the notification (...), it follows that the latter cannot be treated as a decision either". 25

The direct consequence of this is that such notifications cannot be challenged before the Courts because this might move the European judicature to arrive at a decision on questions upon which the Commission had not yet had an opportunity to state its position. This would not only anticipate the arguments on the substance of the case and confuse different administrative and judicial procedural stages, but would also

be incompatible with the system of the division of powers between the Commission and the Courts of the European Communities, with the system of remedies laid down by the Treaty and also with the requirements of the sound administration of justice and the proper course of the administrative procedure to be followed by the Commission. ${ }^{26}$

If the complainant fails to make known its views within the time limit set by the Commission, the complaint is deemed to have been withdrawn. In all other cases, in the third stage of the procedure, the Commission takes cognisance of the observations submitted by the complainant and either initiates a procedure against the subject of the complaint or adopts a decision rejecting the complaint. ${ }^{27}$ The Commission must reason its decision, but it is not obliged to respond to all arguments raised by the complainant. The decision adopted by the Commission at this stage of the procedure can be challenged under Article 263 TFEU before the European Courts.

Van Bael argues that a Commission's decision to reject a complaint does not have a res judicata value, as NCA s, national courts and even the Commission itself at a later stage might reopen the proceedings and find an infringement on the same facts. ${ }^{28}$

Finally, the Notice on the Handling of Complaints provides that throughout the procedure, complainants benefit from procedural rights. However, proceedings of the Commission in competition cases do not constitute adversarial proceedings between the complainant on the one hand and the companies which are the subject of the investigation on the other hand. Accordingly, the procedural rights of complainants are less far-reaching than the right

25 T-64/89, Automec v Commission, quoted above, paragraph 46.

26 T-64/89, Automec v Commission, quoted above, paragraph 46.

27 Commission Notice on the handling of complaints by the Commission under Articles 81 and 82 of the EC Treaty, quoted above, p 71.

Van Bael, op. cit., p. 126. 
to a fair hearing of the companies which are the subject of an infringement procedure. ${ }^{29}$

\subsubsection{Possible Outcomes of the Investigation Phase}

Once the Commission has reached a preliminary view of the main issues raised by a case, different procedural paths may be envisaged.

(1) Prohibition Procedure:The Commission may decide to proceed towards the adoption of a statement of objections with a view to adopting a prohibition decision relating to all or some of the issues identified at the opening of proceedings.

(2) Commitment Procedure: The parties subject to the investigation may consider offering commitments which address the competition concerns arising from the investigation, or at least show their willingness to discuss such a possibility; in that case, the Commission may decide to engage in a discussion with a view to reaching a commitment decision.

(3) Decision to Close the Case: The Commission may decide that there are no grounds to continue the proceedings with regard to all or some of the parties and close the proceedings accordingly. If the case originated from a complaint, the Commission shall, before closing the case, give the complainant the possibility to express their views. ${ }^{30}$

\subsection{Prohibition Procedure}

\subsubsection{Opening of Proceedings and Statement of Objections}

When an initial assessment performed by the Commission leads to a conclusion that there is a case that warrants further investigation, the Commission will open the proceedings. The opening of the proceedings is a formal procedural step provided for by Article 11(6) of the Regulation 1/2003.

Van Bael has argued that during the investigation phase, the parties are often in an "uncomfortable situation" as they usually have no precise knowledge of the reasons for or scope of the investigation. He writes that, "in the course of the investigation, the undertakings have many obligations but very few rights. They are the subject of the investigation, but not really actors in it". ${ }^{31}$

29 Commission Notice on the handling of complaints by the Commission under Articles 81 and 82 of the Ec Treaty, quoted above, p 71 .

30 Commission notice on best practices for the conduct of proceedings concerning Articles 101 and 102 TFEU, quoted above, p. 20.

31 Van Bael, op. cit., p. 166. 
However, this changes with the formal opening of the proceedings, which in the case of cartel investigations coincides with the formulation of the statement of objections. ${ }^{32}$ The opening of the proceedings signals the commitment on the part of the Commission to further investigate the case and to allocate resources for dealing with it in a timely manner. ${ }^{33}$

In addition, the opening of proceedings signals the allocation of the case within the ECN. ${ }^{34}$

The opening of the proceedings will also situate the case in time and identify the persons affected. It will describe the scope of the investigation, the territory and the sectors investigated and the behaviour that constitutes the alleged infringement. ${ }^{35}$ On certain occasions, the Commission will issue a press release to inform the public about its decision to open an investigation. The opening of the proceedings does not limit the right of the Commission to extend the scope and/or the addressees of the investigation at a later point in time. $^{36}$

The importance of the opening of the proceedings is further highlighted by the way in which the Commission communicates its decision to the public. First, the Commission will inform the parties to the investigation, sufficiently in advance, of its intention to make the opening of the investigation public. This communication can take place orally or in writing and is intended to allow the parties to prepare in advance for questions from the press or from the public.

Second, if the Commission decides to make the opening of the proceedings public, it can do so on the website of the Directorate-General for Competition and issue a press release. When such communications risk harming the investigation, the Commission has the discretion to keep the investigation away from the public eye.

Due to the important consequences of publishing such information in the press, the Commission emphasises that the opening of proceedings does not prejudge in any way the existence of an infringement. It merely indicates that

\footnotetext{
32 Commission notice on best practices for the conduct of proceedings concerning Articles 101 and 102 TFEU, quoted above, p. 12.

33 Commission notice on best practices for the conduct of proceedings concerning Articles 101 and 102 TFEU, quoted above, p. 11.

34 Commission notice on best practices for the conduct of proceedings concerning Articles 101 and 102 TFEU, quoted above, p. 11.

35 Commission notice on best practices for the conduct of proceedings concerning Articles 101 and 102 TFEU, quoted above, p. 11.

36 Commission notice on best practices for the conduct of proceedings concerning Articles 101 and 102 TFEU, quoted above, p. 12.
} 
the Commission will pursue the case further. This important clarification will be mentioned in the decision opening the proceedings (notified to the parties), as well as in all public communications concerning the opening of the case. $^{37}$

The statement of objections is signed by the Director-General of DG COMP. The Notice on Best Practices states, however, that the adoption of a statement of objections does not prejudge the final outcome of the investigation. ${ }^{38}$

It is interesting to note that the language used by the Notice on Best Practices clearly suggests that the purpose of the statement of objections is to protect the participants' rights of defence:

Before adopting a decision adversely affecting the interests of an addressee, in particular, a decision finding an infringement of Article 101 and $102 \mathrm{TFEU}$ and ordering its termination and/or imposing fines, the Commission will give the parties subject to the proceedings the opportunity to be heard on the matters to which the Commission has objected. The Commission will do this by adopting a statement of objections, which is notified to each of the parties subject to the proceedings. ${ }^{39}$

The statement of objections marks the passage towards a stage of the proceedings in which the undertakings that are being investigated have procedural rights. The dormant rights of defence are awakened from this point until the end of the proceedings.

When additional objections are issued or the intrinsic nature of the infringement with which an undertaking is charged is modified, the Commission shall notify this to the parties in a supplementary statement of objections and fix a new time limit for the reply to it. ${ }^{40}$

The procedural rights which are triggered by the adoption of the statement of objections apply mutatis mutandis where a supplementary statement of objections is issued, including the right of the parties to request an oral hearing.

37 Commission notice on best practices for the conduct of proceedings concerning Articles 101 and 102 TFEU, quoted above, p. 11.

38 Commission notice on best practices for the conduct of proceedings concerning Articles 101 and 102 TFEU, quoted above, p. 20.

39 Commission notice on best practices for the conduct of proceedings concerning Articles 101 and 102 TFEU, quoted above, p. 21.

40 Commission notice on best practices for the conduct of proceedings concerning Articles 101 and 102 TFEU, quoted above, p. 25. 
Access to all evidence gathered between the initial statement of objections and the supplementary statement of objections will also be provided. ${ }^{41}$

The statement of objections should inform the addressee not only about the Commission's conclusions and the evidence gathered during the investigation, but also about the consequences of being identified as a party to the proceedings.

First, if the Commission intends to impose remedies on the parties, in accordance with Article 7(1) of Regulation 1/2003, the statement of objections will indicate the remedies envisaged that may be necessary to bring the suspected infringement to an end. The information provided to the parties should be sufficiently detailed to allow them to defend themselves as to the necessity and proportionality of the remedies envisaged. When the Commission intends to impose structural remedies, the statement of objections will explain the reasons for which structural remedies are preferred over behavioural remedies. ${ }^{42}$

Second, the statement of objections should clearly indicate whether the Commission intends to impose fines on the undertakings, should the objections be upheld, in accordance with Article 23 of Regulation 1/2003. In such cases, the statement of objections will refer to the relevant principles laid down in the guidelines on setting fines. In the statement of objections, the Commission should indicate the essential facts and matters of law which may result in the imposition of a fine, such as the duration and gravity of the infringement and whether the infringement was committed intentionally or by negligence. The statement of objections should also mention, in a sufficiently precise manner and to the extent possible, the aggravating and attenuating circumstances. ${ }^{43}$

The Commission has the discretion to include in the statement of objections further matters relevant to the subsequent calculation of fines, such as the relevant sales figures to be taken into account and the year(s) that will be considered for the value of such sales. Such information may also be provided to the parties following the issuing of the statement of objections. In both cases, if the Commission chooses to provide such information, the parties will be provided with an opportunity to comment.

As shown above, the Commission is not bound in any way by the conclusions spelled out in the statement of objections. However, if the Commission

41 Commission notice on best practices for the conduct of proceedings concerning Articles 101 and 102 TFEU, quoted above, p. 26.

42 Commission notice on best practices for the conduct of proceedings concerning Articles 101 and 102 TFEU, quoted above, p. 26.

43 Commission notice on best practices for the conduct of proceedings concerning Articles 101 and 102 TFEU, quoted above, p. 21. 
intends to depart from them in its final decision or to disadvantage the undertakings by the remedies or the fines imposed, it has the duty to inform the undertakings of the changed course of action in order to offer the undertakings the possibility to defend themselves.

The Commission might also inform the parties that, in exceptional cases, it may, upon request, take account of the undertaking's inability to pay and reduce or cancel the fine that might otherwise be imposed if that fine would irretrievably jeopardise the economic viability of the undertaking. This is an important safeguard for undertakings that can be triggered by lodging an inability to pay request and providing detailed and up-to-date financial information to support their request. The inability to pay request offers a new opportunity to the parties to bring further relevant information to the attention of the Commission, but also offers the Commission the opportunity to have access to new information about the undertakings that are investigated.

The decision to open proceedings has been delegated to the Competition Commissioner. ${ }^{44}$ As explained above, this decision cannot be challenged in the European Courts because this might result in the judicial branch reaching a decision before the Commission.

\subsubsection{Language Requirements}

Language is an important aspect of every legal procedure. Although not recognised as limit on the Commission's investigative powers, or as a defence right, EU competition law legislation contains extensive provisions concerning the language of the proceedings. First, the documents which the Commission sends to an undertaking based in the European Union should be drafted in the language of the member state in which the undertaking is based. Second, the documents which an undertaking sends to the Commission may be drafted in any one of the official languages of the European Union selected by the sender. The reply and subsequent correspondence should be drafted in the same language. However, in order to avoid delays due to translation, the addressees may waive their right to receive the text in the language of the member state in which the undertaking is based and opt for another language. Duly authorised language waivers can be given for some specific documents or for the whole procedure. ${ }^{45}$

44 Rules of Procedure of the Commission [C(2000) 3614], oJ L 308, 8.12.200o, pp. 26-34, Article 13.

45 Commission notice on best practices for the conduct of proceedings concerning Articles 101 and 102 TFEU, quoted above, p. 12. 
During the investigation phase, the language requirements are less strict and the Commission may send simple requests for information in the language of the addressee's location or in English and attach the questionnaire in English. The addressee must also be clearly informed - in the language of the addressee's location - of its right to obtain a translation of the cover letter and/or questionnaire into the language of the addressee's location, as well as the right to reply in that language. This practice allows for more expeditious treatment of information requests, while preserving the rights of addressees. ${ }^{46}$

In the later stages of the procedure, though, the Commission has the duty to communicate in the authentic language of the addressee. Thus, the statement of objections, the preliminary assessment and the decisions adopted pursuant to Articles 7, 9 and 23(2) of Regulation 1/2003 should be notified in the authentic language of the addressee unless it has signed the above-mentioned language waiver. The reply and all subsequent correspondence addressed to the complainant should be in the language of their complaint. ${ }^{47}$

Finally, participants in the oral hearing may request to be heard in an EU official language other than the language of proceedings. In that case, interpretation should be provided during the oral hearing, as long as sufficient advance notice of this requirement is given to the hearing officer. ${ }^{48}$

\subsubsection{In-depth Analysis Prior to the Adoption of a Prohibition Decision}

When the Commission acquires new evidence that will be used in a decision, it must bring this to the attention of the parties concerned by a letter of facts. The letter of facts gives undertakings the opportunity to provide written comments on the new evidence within a fixed time limit. A request for an extension of this time limit may be made by way of a reasoned request to the Commission. If the Directorate-General for Competition and the addressee disagree about a requested extension, the addressee may refer the matter to the hearing officer by means of a reasoned request. ${ }^{49}$ If a letter of facts is issued, access would in general be granted to evidence gathered after the statement of objections up to the date of the said letter of facts. However, in cases where the Commission

46 Commission notice on best practices for the conduct of proceedings concerning Articles 101 and 102 TFEU, quoted above, p. 12.

47 Commission notice on best practices for the conduct of proceedings concerning Articles 101 and 102 TFEU, quoted above, p. 12.

48 Commission notice on best practices for the conduct of proceedings concerning Articles 101 and 102 TFEU, quoted above, p. 12.

49 Commission notice on best practices for the conduct of proceedings concerning Articles 101 and 102 TFEU, quoted above, p. 25. 
intends to rely only upon specific evidence that concerns one or a limited number of parties and/or isolated issues (in particular those regarding the determination of the amount of the fine or issues of parental liability), access would be provided only to the parties directly concerned and to the evidence relating to the issue(s) in question. ${ }^{50}$

Only the documents mentioned in the statement of objections may be treated as admissible evidence against an undertaking. This point was raised in ICI in which the applicant company complained that, when the Commission sent it the statement of objections, it did not send it all the documents on which it based the decision and that the Commission thus made it impossible for them to explain their contents. The Court highlighted that according to its case-law,

the important point is not the documents as such but the conclusions which the Commission has drawn from them, and if those documents were not mentioned in the statement of objections, the undertaking concerned was entitled to take the view that they were of no importance for the purposes of the case. By not informing an undertaking that certain documents would be used in the Decision, the Commission prevented it from putting forward at the appropriate time its view of the probative value of such documents. It follows that those documents cannot be regarded as admissible evidence. ${ }^{51}$

The translation of the facts discovered into legal reasoning is an important step in every procedure. The intermediate legal interpretation of facts offered by the Commission to the undertakings in its statement of objections can, however, be transformed, adapted or given up in the final legal reasoning put forward in the decision. This issue was raised in the case of Mannesmannrohren-Werke where the applicant undertaking complained that the discrepancy in legal reasoning between the statement of objections and the Commission's Decision breached its rights of defence. In that regard, the Court noted that

the legal classification of the facts made in the statement of objections can, by definition, be only provisional, and a subsequent Commission decision cannot be annulled on the sole ground that the definitive conclusions drawn from those facts do not correspond precisely with

\footnotetext{
50 Commission notice on best practices for the conduct of proceedings concerning Articles 101 and 102 TFEU, quoted above, p. 26. 
that intermediate classification. The Commission is required to hear the addressees of a statement of objections and, where necessary, to take account of any observations made in response to the objections by amending its analysis specifically in order to respect their rights of defence. ${ }^{52}$

The Notice on Best Practices explains that throughout the procedure, the Directorate-General for Competition endeavours to offer the parties, on its own motion or upon request, "ample opportunity for open and frank discussions - taking into account the stage of the investigation - and to make their points of view known". ${ }^{3}$ This is achieved by organizing state of play meetings, triangular meetings and meetings with the Commissioner or the Director-General.

State of play meetings can be offered to the parties being investigated for the purpose of contributing to the "quality and efficiency of the decision-making process and to ensure transparency and communication". ${ }^{54}$ In the context of cartel proceedings, one state of play meeting will be offered after the oral hearing. Furthermore, two specific state of play meetings will be offered in the context of procedures leading to commitment decisions and to complainants where the Commission has opened proceedings under Article 11(6) of Regulation $1 / 2003$ and intends to inform the complainant that it will reject its complaint by formal letter. ${ }^{55}$

State of play meetings can be conducted at the Commission's premises or held by telephone or videoconference. They are chaired by the Director-General, Deputy Director-General or by the responsible head of unit.

Triangular meetings are meetings held between the Directorate-General for Competition, the undertakings being investigated and the complainant and/or third parties. The purpose of triangular meetings is "to verify the accuracy of factualissues of all the partiesin a single meeting (...) for example, wheretwo ormore opposingviewsorinformationhavebeenputforwardastokeydataorevidence". ${ }^{56}$

52 T-44/oo, Mannesmannrohren-Werke v Commission, quoted above, paragraph 100.

53 Commission notice on best practices for the conduct of proceedings concerning Articles 101 and 102 TFEU, quoted above, p. 17.

54 Commission notice on best practices for the conduct of proceedings concerning Articles 101 and 102 TFEU, quoted above, p. 18.

55 Commission notice on best practices for the conduct of proceedings concerning Articles 101 and 102 TFEU, quoted above, p. 18.

56 Commission notice on best practices for the conduct of proceedings concerning Articles 101 and 102 TFEU, quoted above, p. 19. 
Triangular meetings are chaired by the Director-General or Deputy DirectorGeneral. ${ }^{57}$

Lastly, the Notice on Best Practices states that

it is normal practice to offer senior officers of the parties subject to the proceedings and the complainant an opportunity to discuss the case either with the Director-General for competition, the Deputy DirectorGeneral for antitrust, or if appropriate, with the Commissioner responsible for Competition. The senior officers may be accompanied by their legal and/or economic advisors. ${ }^{58}$ (emphasis added)

Once the Commission has finished collecting and assessing the facts, and once the parties concerned have had an opportunity to challenge them orally or in writing, the Commission may adopt a prohibition decision. The Commission established a few checks and balances in order to ensure that all relevant views and evidence are properly taken into account before a final decision is adopted, and that the assessment proposed by the case team is sound and takes account of parties' arguments. ${ }^{59}$ At the same time, these checks and balances are part of the Commission's internal deliberation process and the documents produced during these deliberations are generally not part of the accessible file.

The internal checks and balances to the DG COMP put in place are (1) the chief economist, (2) peer review, (3) the hearing officer, (4) the legal service and other associated Commission services and (5) the advisory committee.

The chief economist's task is to assist in evaluating the economic impact of the Commission's actions in the field of competition, and to provide guidance on issues of economics and econometrics in the application of EU competition rules. The chief economist contributes to individual competition cases, in particular in cases involving complex economic issues and quantitative analysis. At the request of the legal service, the chief economist assists with cases pending before the Court of Justice of the European Union. ${ }^{60}$

57 Commission notice on best practices for the conduct of proceedings concerning Articles 101 and 102 TFEU, quoted above, p. 19.

$5^{8}$ Commission notice on best practices for the conduct of proceedings concerning Articles 101 and 102 TFEU, quoted above, p. 19.

59 European Commission. Directorate-General for Competition. Proceedings for the application of Articles 101 and 102 TFEU: Key Actors and Checks and Balances. Page 2. Available at http://ec.europa.eu/competition/antitrust/key_actors_en.pdf accessed on 23 February 2021.

6o European Commission. Directorate-General for Competition. Proceedings for the application of Articles 101 and 102 TFEU: Key Actors and Checks and Balances, quoted above, p. 2. 
Peer review was initially used in complex merger cases, but was later extended to other types of in-depth investigation. ${ }^{61}$

The Commission explains that peer review is an instrument intended to provide a "fresh pair of eyes" to look at all or certain aspects of the assessment performed by the case team. It is the Director-General, together with the Commissioner, who decide which cases will be reviewed by peer review panel. A peer review team is appointed for this purpose.

The organisation of the panel and the members of the peer review team are not made public and the peer review of a case does not involve the parties. The peer review team is granted full access to the file and the case team.

The aim of the Peer Review Panel is to have an open discussion on the line proposed by the case team. The Panel will "either identify areas where further work is necessary; identify objections that should be dropped; recommend that the case is not pursued further; or recommend that the case team continue with the case on an unchanged basis. The Panel's recommendations are purely internal and are not disclosed to the parties to the proceedings, complainants or any other third party". ${ }^{2}$

The findings and recommendations of the Panel are reported to the DirectorGeneral, who is then responsible for making a proposal to the Commissioner that reflects all available evidence and analysis.

The Hearing Officers are appointed by the President of the Commission for the purpose of ensuring that procedural rights are safeguarded during the proceedings. The hearing officer organises and conducts the oral hearing and reports to the Competition Commissioner on it. Generally, the hearing officer may present to the Competition Commissioner observations on any matter arising out of the proceedings. He/she also prepares a final report to the College of Commissioners before the final decision is taken. ${ }^{63}$

DG COMP must also consult the Commission's legal service and other DG $s$ responsible for the products, services or policy areas concerned in a particular case. $^{64}$

61 Van Bael, Ivo and Jean-François Bellis. Competition Law of the European Community. Bruxelles: Kluwer Law International, 2005, p. 11.

62 European Commission. Directorate-General for Competition. Proceedings for the application of Articles 101 and 102 TFEU: Key Actors and Checks and Balances, quoted above.

63 European Commission. Directorate-General for Competition. Proceedings for the application of Articles 101 and 102 TFEU: Key Actors and Checks and Balances, quoted above, p. 3.

64 European Commission. Directorate-General for Competition. Proceedings for the application of Articles 101 and 102 TFEU: Key Actors and Checks and Balances, quoted above, p. 4. 
Finally, Article 14(1) of Regulation 1/2003 indicates that the Commission shall consult an Advisory Committee on Restrictive Practices and Dominant Positions prior to the taking of any decision concerning:

- A finding and termination of infringement;

- Interim measures;

- Commitment decisions;

- A finding of inapplicability of Article 101 or 102;

- Imposition of fines;

- Final imposition of a periodic penalty; or

- The withdrawal of the benefit of a block exemption in individual cases.

The Advisory Committee is composed of representatives of the competition authorities of the member states. For meetings in which issues other than individual cases are being discussed, an additional member state representative competent in competition matters may be appointed. ${ }^{65}$

Although the Commission shall take the utmost account of the opinion delivered by the advisory committee, it is not bound by it. However, the Commission shall inform the committee of the manner in which its opinion has been taken into account. ${ }^{66}$ In addition, where the advisory committee delivers a written opinion, this opinion shall be appended to the draft decision.

\subsubsection{Formal Adoption of a Prohibition Decision}

The final step towards the adoption of a prohibition decision - after the investigation and decision-making phases - is the formal adoption of the decision. Article 4 of the Rules of Procedure provides that the Commission's decisions can be taken at meetings, or, alternatively, by written procedure, by empowerment or by delegation.

The written procedure is provided for in Article 12 of the Rules of Procedure of the Commission. This procedure implies that the text of the proposal be circulated in writing to all Members of the Commission with a time limit within which members must make known any reservations or amendments they wish to make. Proposals on which no Member of the Commission has made reservations, with which the Directorates-General directly involved are

65 Council Regulation (EC) No 1/2003 of 16 December 2002 on the implementation of the rules on competition laid down in Articles 81 and 82 of the Treaty, quoted above, article $14(2)$.

66 Council Regulation (EC) No 1/2003 of 16 December 2002 on the implementation of the rules on competition laid down in Articles 81 and 82 of the Treaty, quoted above, article $14(5)$. 
in agreement and which are endorsed by the legal service, shall stand adopted by the Commission.

Van Bael notes that due to the heavy workload of the Commission, most competition decisions are adopted by the Commission without any debate, by the written procedure. ${ }^{67}$ Schwarze has noted that the written procedure "raises no doubts of a legal nature, since it preserves the basic responsibility of all commissioners and merely alters the voting procedure in a way that is not crucial".68

An illustration of written procedure can be found in Buchler, wherein the applicants complained that the Commission's decision should be declared invalid due to the fact that the Commissioners had not received a complete file of the case. The Court replied that the Members of the Commission received complete and detailed information regarding the essential points of the case and had access to the entire file. ${ }^{69}$

Alternatively, Article 13 of the Rules of Procedure provides that the Commission might - provided that the principle of collective responsibility is fully respected - empower one or more of its Members (1) to take management or administrative measures on its behalf; (2) to adopt the definitive text of any instrument or proposal to be presented to other institutions the substance of which has already been determined in discussion; or (3) to subdelegate the above-mentioned powers to the Directors-General and Heads of Service.

The empowerment and delegation procedures appear to be more problematic. Except for the brevity and expediency of their formulation, Schwarze highlighted that the legitimacy of the transfers of power is problematic because they diminish "the responsibility of the collegiate body as a whole".70

After the formal adoption of a decision by the College of Commissioners, the Commission will notify the decision to the parties and will publish it in the Official Journal of the European Union.

\subsection{Commitments Procedure}

Article 9(1) of Regulation 1/2003 stipulates that

where the Commission intends to adopt a decision requiring that an infringement be brought to an end and the undertakings concerned

67 Van Bael, op. cit., p. 210.

68 Schwarze, op. cit., p. 1209.

69 C-44/69, Buchler \& Co. v Commission, ECLI:EU:C:1970:72, paragraph 22.

70 Schwarze, op. cit., p. 1210. 
offer commitments to meet the concerns expressed to them by the Commission in its preliminary assessment, the Commission may by decision make those commitments binding on the undertakings. Such a decision may be adopted for a specified period and shall conclude that there are no longer grounds for action by the Commission.

The main difference between a prohibition decision pursuant to Article 7 and a commitment decision pursuant to Article 9 of Regulation 1/2003 is that the former contains a finding of an infringement while the latter makes the commitments binding without a statement of infringement. A commitment decision will conclude, however, that, in light of the commitments offered, there are no longer grounds for action by the Commission. Moreover, unlike Article 7 decisions, commitments are offered by undertakings on a voluntary basis. ${ }^{71}$ Former Commissioner Almunia stated that "commitments invite a cooperative attitude on the part of the companies, which I always regard as a good thing".72

Commissioner Almunia noted that both the undertakings and the Commission benefit from pursuing this procedure. On the one hand, most companies involved in anti-competitive practices accept the commitment procedure and go for the solution that can best protect their interests and reputation, allowing for a faster closing of the case and without a formal acceptance of wrongdoing. The Commission on the other hand, appreciates the swiftness and flexibility that the commitment procedure brings. ${ }^{73}$

It is for the undertakings to approach DG COMP to explore the Commission's readiness to pursue the case with the aim of reaching a commitment decision. The commitments may be offered from the moment of the initiation of the proceedings until the moment when the Commission adopts a decision, although undertakings will be encouraged to open the floor for discussing commitments as early as possible.

Once the undertakings have expressed an interest in discussing commitments, DG COMP will indicate the timeframe within which the discussions on potential commitments should be concluded and will present to them the preliminary competition concerns arising from the investigation.

71 Commission notice on best practices for the conduct of proceedings concerning Articles 101 and 102 TFEU, quoted above, p. 26.

72 European Commission. Joaquin Almunia. Remedies, Commitments and Settlements in Antitrust. Speech, 8 Mar 2013. Available at http://europa.eu/rapid/press-release_SPEECH13-210_en.htm accessed on 23 February 2021.

European Commission. Joaquin Almunia, quoted above. 
Although neither Regulation 1/2003, nor the Implementing Regulation define what the elements of a preliminary assessment should be, in practice it is a written letter addressed to the undertaking(s) concerned in which the Commission describes the facts, the behaviour under scrutiny, the legal basis of the decision and the competition law concerns that justify the adoption of a decision.

The Commission must conduct a market test of the proposed commitments before making them binding by decision. The Commission will only conduct a market test if it considers that the commitments offered prima facie address the competition concerns identified. The Commission must publish in the Official Journal of the European Union a market test notice containing a concise summary of the case and the main content of the commitments, whilst respecting the obligations of professional secrecy. It will also publish on the DG comp's website the full text of the commitments in the authentic language. In order to enhance the transparency of the process, the Commission will also publish a press release setting out the key issues of the case and the proposed commitments. ${ }^{74}$

There is no time limit to these negotiations; in difficult cases the negotiations can continue until the very last minute.

If the undertakings are unwilling to submit an amended version of the commitments, the Commission can revert to the Article 7 procedure.

If an agreement is reached, the Commission will adopt a decision pursuant to Article 9(1) of Regulation 1/2003 making the commitments binding and thus enforceable.

\subsection{Procedure for Rejection of Complaints}

The Commission may, after appropriate assessment of the factual and legal circumstances of an individual case, reject a complaint. The rejection of complaints can be justified by (1) insufficient grounds for acting; (2) lack of competence or (3) lack of evidence.

If the Commission, after careful examination of a case, comes to the preliminary conclusion that it should not pursue the case, it will inform the complainant in a meeting or by phone that it has come to the preliminary view that the case should be rejected. This gives the opportunity to the complainant 74 Commission notice on best practices for the conduct of proceedings concerning Articles
101 and 102 TFEU, quoted above, p. 28 . 
to withdraw its complaint. Otherwise, the Commission will inform the complainant by a formal letter of its preliminary findings and set a time limit for its written observations. In this context, the complainant has the right to request access to the documents on which the Commission bases its provisional assessment. ${ }^{75}$

If the complainant does not answer the Commission's letter, the complaint will be considered to be withdrawn on the basis of Article 7(3) of the Implementing Regulation. If the complainant replies by providing information that does not change its preliminary assessment, the Commission will reject the complaint by a decision on the basis of Article $7(2)$ of the Implementing Regulation.

\subsection{Settlement Procedures}

There are currently two settlement procedures used by the Commission: the informal settlement procedure and the formal settlement procedure.

Very little is known about the procedure by which the Commission informally settles competition law cases. Van Bael has estimated that more than $90 \%$ of infringement cases are closed using the informal settlement procedure. ${ }^{76} \mathrm{He}$ argues that informal settlements take place "in a purely negotiated and informal way, without any clear procedural steps and usually with very limited publicity". ${ }^{77} \mathrm{He}$ concludes that "the core weakness of informal settlements is that they do not lead to any formal decision".78

Another author has highlighted that despite the introduction of the commitment procedure, the Commission still continues, as before the entry into force of Regulation 1/2003, to settle cases informally, provided it considers such a solution appropriate in its antitrust enforcement action. ${ }^{79}$ The author puts forward the example of the case where the Commission welcomed the new iPhone policies announced by Apple. Formal antitrust proceedings were commenced against Apple in 2007 in cases COMP/39154 PO/iTunes and COMP/

75 Commission notice on best practices for the conduct of proceedings concerning Articles 101 and 102 TFEU, quoted above, p. 29.

76 Van Bael, op. cit., p. 290.

77 Van Bael, op. cit.

78 Van Bael, op. cit., p. 292.

79 Cavicchi, Piero. "The European Commission's Discretion as to the Adoption of Article 9 Commitment Decisions: Lessons from Alrosa." Discussion paper// Europa-Kolleg Hamburg, Institute for European Integration 3 (2011), p.5. Available at http://hdl.handle. net/10419/45859 accessed on 23 February 2021. 
39174 Which/iTunes, before the Commission decided to close them in light of Apple's announcement that it would equalise prices for downloading songs from its iTunes online store in Europe..$^{80}$

The European Commission introduced the formal settlement procedure in 2008 as a package comprising:

- Commission Regulation (EC) No 622/2008 of 30 June 2008 amending Regulation (EC) No 733/2004, as regards the conduct of settlement procedures in cartel cases; and

- Commission Notice on the conduct of settlement procedures in view of the adoption of Decisions pursuant to Article 7 and Article 23 of Council Regulation (EC) No 1/2003 in cartel cases which describes the new procedure in detail.

The rationale for these legislative changes, as explained in their preambles, is three-fold and includes: (1) the need for a simplified procedure; (2) the need to acknowledge and reward the parties voluntarily cooperating with the Commission and thus promote a culture of cooperation; and (3) the need to reduce litigation before the European Courts in cartel cases.

The Competition Commissioner commented at the time of the adoption of the package that

this new settlement procedure will reinforce deterrence by helping the Commission deal more quickly with cartel cases, freeing up resources to open new investigations. Companies which are convinced that the Commission can prove their involvement in a cartel, will also benefit from quicker decisions and a fine reduction. ${ }^{81}$

The settlement procedure applies only to cartel cases. As pointed out "since cartels are deliberate, flagrant infringements, in such cases the debate between the suspect companies and the Commission focuses on the scope and accuracy of the facts and on the value and extent of evidence in the file". ${ }^{82}$ Indeed, due to the fact that discussions about intent, market definition, pro and

8o European Commission. "Antitrust: European Commission Welcomes Apple's Announcement to Equalise Prices for Music Downloads from iTunes in Europe." Press Release Database IP/o8/22. 9 Jan 2008. Available at http://europa.eu/rapid/press-release_ IP-o8-22_en.htm accessed on 23 February 2021.

81 European Commission. "Antitrust: Commission Introduces Settlement Procedure for Cartels." Press Release Database IP/08/1056. 30 Jun 2008. Available at http://europa.eu/ rapid/press-release_IP-o8-1056_en.htm accessed on 23 February 2021. 
anti-competitive effects are missing, the settlement discussions "are not meant to extract more evidence but to debate the preliminary findings and the evidence already gathered by the Commission". 83

The Commission Notice on Settlement describes the six stages of the formal settlement procedure in cartel cases: (1) investigation as usual; (2) exploratory steps regarding settlement; (3) bilateral rounds of settlement discussions; (4) settlement; (5) 'settled' statement of objections; and (6) 'settlement' decision. ${ }^{84}$

As a normal investigation takes place before the settlement phase, settlements do not mean "investigative shortcut". On the contrary, "the Commission enters into this phase only when it has sufficient elements to proceed with the case in standard procedure". ${ }^{85}$

There is no monopoly on the right to propose the settlement of the case; either of the parties or the Commission may express interest in this procedure. The Commission, however, has a broad margin of discretion to choose the cases which are suitable for settlement, to decide to engage in settlement discussion, to discontinue them or to pursue the settlement procedure until the end. ${ }^{86} \mathrm{~A}$ general principle, though, is that the settlement procedure cannot be imposed on the parties. ${ }^{87}$ The Commission's broad margin of discretion in the settlement procedure extends to the reasons for choosing to take the path of settlement. In this regard, account may be taken of the probability of reaching a common understanding regarding the scope of the potential objections in light of the provisional calendar, the number of parties involved and the foreseeable conflicting positions. The Commission's decision may also be informed by the prospect of achieving efficiencies and the possibility of creating a precedent..$^{88}$

83 Tierno Centella, op. cit., p. 31 .

84 Commission Notice on the conduct of settlement procedures in view of the adoption of Decisions pursuant to Article 7 and Article 23 of Council Regulation (EC) No 1/2003 in cartel cases, oJ C 167, 2.7.2008, pp. 1-6.

85 Laina, Flavio, and Elina Laurinen. "The EU Cartel Settlement Procedure: Current Status and Challenges." Journal of European Competition Law and Practice 4.4 (2013): pp. 302311, p. 2.

86 Council Regulation (EC) No 1/2003 of 16 December 2002 on the implementation of the rules on competition laid down in Articles 81 and 82 of the Treaty, quoted above, preamble 4 .

87 Commission Notice on the conduct of settlement procedures in view of the adoption of Decisions pursuant to Article 7 and Article 23 of Council Regulation (EC) No 1/2003 in cartel cases, quoted above, p. 1.

88 Council Regulation (EC) No 1/2003 of 16 December 2002 on the implementation of the rules on competition laid down in Articles 81 and 82 of the Treaty, quoted above, preamble 4 . 
When the Commission decides to explore the parties' interest to engage in settlement discussions, it will set a time limit of a minimum of two weeks within which the parties may express in writing their interest in pursuing this procedural option.

The next stage of the settlement procedure comprises bilateral rounds of settlement discussions that start when one or a few parties make a request to settle. The bilateral rounds of discussions move gradually toward a more intense exchange of information between the Commission and the parties. The Commission retains the discretion to determine the appropriateness of the pace, the timing of disclosing evidence and the potential fine. ${ }^{89}$ No formal records of the settlement discussions are kept at this stage because this "allows the parties to have frank exchanges and helps protect confidentiality of settlement discussions". ${ }^{90}$

Laina and Laurinen acknowledged that this is "a challenging process, as intensive and confidential bilateral discussions are carried out in parallel with all parties and consensus must be reached with all of them". ${ }^{91}$ They emphasise that by no means is participation in settlement discussions synonymous with an admission of an infringement, a conclusion that can only be reached at the end of the bilateral discussions. ${ }^{92}$

During the discussions, parties may submit technical papers or 'non-papers' which address various technical aspects of the case in order to facilitate the discussions, but which cannot be used as evidence. ${ }^{93}$

After the bilateral discussions, parties may introduce a formal request to settle in the form of a settlement submission. The settlement submissions should contain the following elements: (1) a clear and unequivocal acknowledgement of the of the parties' liability for the infringement, including the main facts, their legal qualification, the role played by the party in the infringement, and the duration of their participation; (2) the maximum amount of the fine that the party foresees and that they would accept; (3) a statement that they have been sufficiently informed and that they had sufficient opportunity to make their views known; (4) a statement that they do not envisage requesting access to the file or to be heard in the oral hearing; and (5) the parties' agreement to

89 Commission Notice on the conduct of settlement procedures in view of the adoption of Decisions pursuant to Article 7 and Article 23 of Council Regulation (EC) No 1/2003 in cartel cases, quoted above, p. 3 .

$90 \quad$ Tierno Centella, op. cit., p. 33.

$91 \quad$ Laina and Laurinen, op. cit., p. 3.

92 Laina and Laurinen, op. cit.

93 Laina and Laurinen, op. cit., p. 4. 
receive the statement of objections and the final decision in an agreed language of the European Union. ${ }^{94}$ The settlement request is an important step and, once the party makes it, it cannot be withdrawn.

The Commission retains the right, after the receipt of the settlement request, to adopt a statement of objections that reflects the parties' settlement request and thus continue the settlement procedure or to disregard the request and adopt a prohibition decision.

However, after the parties' replies to the statement of objections confirming their commitment to settle, the Commission may proceed to the adoption of the final decision pursuant to Articles 7 and/or 23 of Regulation 1/2003. ${ }^{95}$ The cooperation towards settlement will be mentioned by the Commission in its final decision. When the Commission decides to reward the party for settlement, it will reduce the fine by $10 \% .{ }^{96}$

Settlement decisions are adopted in the same way as prohibition decisions. They will include a finding of an infringement and a fine.

One author concluded that the Settlement Package shows that the Commission "does not rest on its laurels, but actively searches for ways to maintain and improve its performance and record against a moving target, so that its enforcement efforts increase deterrence against cartel behaviour". ${ }^{97}$

94 Commission Notice on the conduct of settlement procedures in view of the adoption of Decisions pursuant to Article 7 and Article 23 of Council Regulation (EC) No 1/2003 in cartel cases, quoted above, p. 3 .

95 Commission Notice on the conduct of settlement procedures in view of the adoption of Decisions pursuant to Article 7 and Article 23 of Council Regulation (EC) No 1/2003 in cartel cases, quoted above, p. 4.

96 Commission Notice on the conduct of settlement procedures in view of the adoption of Decisions pursuant to Article 7 and Article 23 of Council Regulation (EC) No 1/2003 in cartel cases, quoted above, p. 5 .

Tierno Centella, op. cit., p. 35 . 